\title{
The Influence of Capital and Work Environment on The Performance of MSME Employees of Bogor Regency West Java Province by Covariable Marketing
}

\author{
Ismartaya \\ Management Study Program Faculty of Economics, University of Djuanda Bogor Indonesia \\ ${ }^{*}$ Corresponding author: \\ Email: ismartaya@unida.ac.id
}

\begin{abstract}
.
Micro, small and medium enterprises or MSMEs in Indonesia each year increase. The increasing number of MSMEs still needs to experience intensive assistance in order to achieve independent, resilient, and quality MSMEs. Employee performance is a form of employee achievement after going through various stages in the work process. Based on the observations, researchers showed that the performance of MSME employees in Babakan Madang subdistrict and Cisarua Sub-District of Bogor Regency was not optimal. This is allegedly due to being influenced by capital, work environment, and marketing. The formulation of problems in this research is whether the capital and work environment can affect the performance of employees directly or through the marketing of MSMEs in two sub-districts in Bogor Regency. This study aims to find out the influence of capital and work environment on employee performance with marketing co-operation on MSMEs Bogor Regency, this research uses the archework of The Posttest Only Control Group with marketing covariance. Data collection techniques use interviews and questionnaires, while sampling techniques use non probability sampling with a sample number of 72 people. The results showed that capital and work environment have a positive and significant effect on employee performance through marketing. This can be seen from the results of simple linear regression analysis, multiple linear regression, $t$ test, determination coefficient test, sobel test and path analysis. Marketing as a moderator variable mediates between capital to employee performance that is partial mediation and marketing as moderator variables that mediate between the work environment and employee performance, both of which are full mediation.
\end{abstract}

Keywords: Capital, Work Environment, Marketing, Employee Performance

\section{INTRODUCTION}

The development of MSMEs in Indonesia, especially in Bogor Regency continues to grow due to the increasing economic growth. The existence of capital, work environment and marketing are the keys to the success of a business. MSME businesses need the presence of capital, work environment and marketing to increase sales of their products and expand the reach of the market. This is important so that the products or services offered by MSMEs can be known to the wider community, especially Bogor Regency and its surroundings. MSMEs in Bogor Regency are one of the right steps in improving the welfare of the community because it is able to move the economy and provide business opportunities to the community. With the 
development of good and structured MSMEs can also reduce poverty and social inequality that we still often find in Bogor Regency. Therefore, human resources as an important factor in this industry must be developed optimally. Please note that businesses still use traditional principles in marketing their products that will make the development of the road business in place [1].

Understanding SMEs refers to the MSME Law No. 20 of 2008, namely: Micro, Small, and Medium Enterprises (MSMEs) is a business activity that is able to expand employment and provide broad economic services to the community, play a role in the process of equalization and increase people's income, encourage economic growth, and realize national economic stability The main role of SMEs is as the main driver of the wheels of Indonesian economic activities, employment opportunities that absorb a lot of labor, an important role that makes the regional economy and community development to develop, which creates a growing market and always strives to innovate between corporate activities and the latter is as a player in improving the international balance of payments through an increasingly tangible role in the composition of exports and foreign exchange savings through import substitution products attributed by SMEs (Urata 2002). SMEs also have a considerable role in exports and investment. So that the opportunities of SMEs in the future in developing a product through the world market has considerable potential, preferably accompanied by the development of products that are more creative, innovative and have a good work environment.[2]

According to Syafri the capital itself is the owner equity of which equity is a remaining right to the assets of an institution after deducting its obligations[1]. In the opinion of Ali, A. and Agustin, S. (2015) defines capital as a power to use capital goods. Thus the capital is in the balance sheet next to the credit. The capital goods are items in the company that have not been used in the balance sheet next to the debit.[3]

The work environment in a company is very important for management to pay attention to. Although the work environment does not carry out the production process in a company, but the work environment has a direct influence on the employees who carry out the production process. The work environment is an atmosphere where employees do activities every day. According to Nuraini (2013:97) the work environment is everything around the employee and can affect the task carried out to him for example with the presence of airconditioner (AC), adequate lighting and so on. The work environment is something that exists in the environment of workers who can protect themselves in carrying out tasks such as temperature, humidity, ventilation, lighting, noise, cleanliness of the workplace and adequate lack of work equipment. [5].

According to Stanton in Tambajong (2013:1293), marketing is a system of business activities designed to plan, price, promote and distribute products that can satisfy desires in achieving the company's goals. [6]

Marketing as the process by which companies create value for customers and build strong customer relationships in order to capture value from customers in return", 
means stating that marketing is a process by which companies create value for customers and build strong customer relationships to capture value from customers in return.[7]

According to Melydrum in Sudaryono (2016:41), marketing is a business process that seeks to align the human, financial and physical resources of the organization with the needs and desires of its customers in the context of competitive strategies. So it can be concluded, marketing is an economic activity carried out to meet the needs and desires of consumers with products that have been offered by the company .[8]

According to Mangkunegara (2013:67), employee performance is the performance of work or work results both quality and quantity achieved by the human resources of the union period of time in carrying out its work duties in accordance with the responsibilities given to him [9]. Whereas according to Amirullah (2015:231), performance is all results produced there is a function of work or special activity during a special period [10]. From the above understanding, it is concluded that performance is the result of a certain work process planned at the time and place of certain employees and organizations. According to Simanjuntak (2011:1), performance is the level of achievement of results for the implementation of certain tasks. Performance management is the overall activity carried out to improve the performance of the company or organization, including the performance of each individual and the working group of the company[11]. The meaning of the word performance comes from the word job performance and is also called actual performance or actual achievements that have been achieved by an employee [12].

In his book concludes the understanding of employee performance or performance deficiency as a result of performance that can be achieved by a person or group of people in an organization both qualitatively and quantitatively, in accordance with their respective authority, duties and responsibilities in an effort to achieve the objectives of the organization legally, not in violation of the law and in accordance with morals or ethics[13].

From this background, researchers are interested in conducting research in MSMEs in Babakan Madang Subdistrict and Cisarua District of Bogor Regency entitled "The Influence of Capital and Work Environment on Employee Performance through Marketing as a Variable Convariable (Case Study of MSMEs in Babakan Madang subdistrict and Cisarua District of Bogor Regency)". So that the problems can be formulated in this research are as follows:

1. Is there any influence between capital on employee performance?

2. Is there any influence of capital on marketing?

3. Is there any effect of the work environment on employee performance?

4. Is there any influence of the work environment on marketing? 
5. Is there any influence of marketing as a moderator variable on Employee Performance?

6. Is there any influence of capital on employee performance through marketing?

7. Is there any influence of the work environment on employee performance through marketing?

The hypotheses used in this study are as follows:

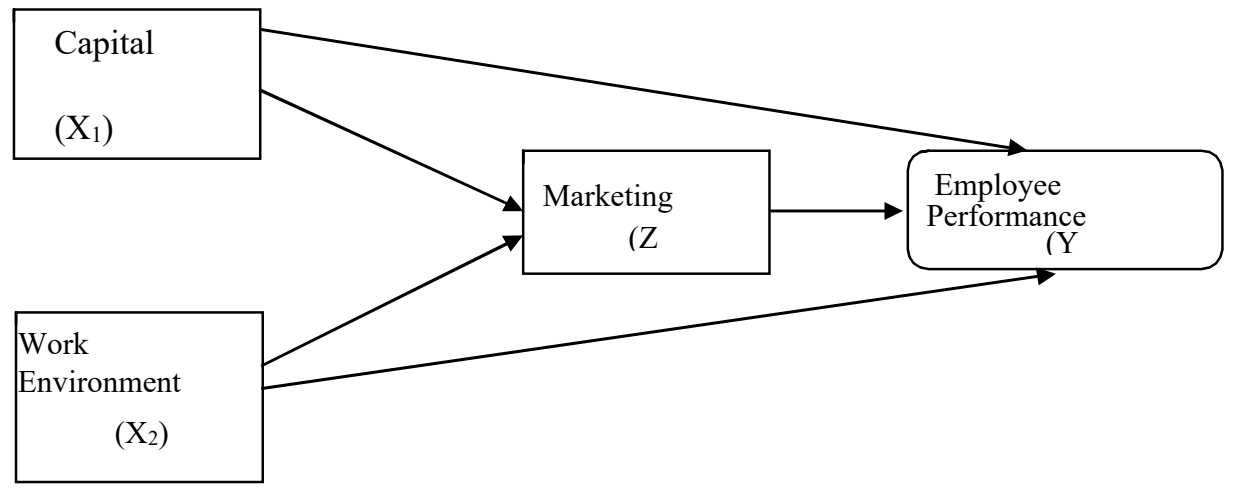

Source: Processed and developed for research, 2020

The hypothesis formulation in this study is as follows:

1. H1: It is suspected that there is an influence between capital on employee performance

2. H2: Suspected influence between capital on marketing

3. H3: It is suspected that there is an influence between the work environment on employee performance.

4. H4: Suspected influence between work environment and marketing

5. H5: It is suspected that there is an influence between marketing as a Variable Convariable to employee performance.

6. H6: It is suspected that there is a capital influence on employee performance through marketing

7. H7: It is suspected that there is an influence of the work environment on employee performance through marketing.

\section{METHODS}

This research is an experimental research. Experiments were conducted on MSME groups in two subdistricts in Bogor Regency that already existed because researchers were unlikely to change the structure of existing MSME groups. Thus, this research is categorized as quasi experiments.

This research plan follows the research design of post-test only control experiments while the population in this study is MSMEs in two sub-districts namely 
Babakan Madang and Cisarua subdistricts. While the number of samples in this study as many as 72 respondents. Sampling techniques that penelitu use is saturated samples, namely sampling techniques by taking all populations in two subdistricts in Bogor Regency. The measurement scale uses a likert scale, and the instruments used are questionnaires and interviews. This research uses qualitative and quantitative analysis techniques. Quantitative analysis using spss program, by testing validity and reliability test, then correlation coefficient test, simple linear regression test to know the influence and direction of each independent variable $(\mathrm{X})$ on dependent variable $(\mathrm{Y})$ and variable moderator $(Z)$, after which test the coefficient of determination, and $t$ test is done to see how far the influence of one independent variable individually in explaining the dependent variable, then multiple linear regression to know how dependent variable state $(\mathrm{Y})$

If two or more independent variables (X) are up and down, as well as sobel test which is a test to find out if the relationship through a mediation variable is significantly capable as a mediator in the relationship. So the researchers tried to use sobel test to find out how far mediation of intervening variables $(Z)$ together can affect the dependent variable (Y). Where Sobel test using $\mathrm{z}$ test with the following formula:

$$
z=\frac{a b}{\sqrt[a]{\left(b^{2} S E_{b}^{2}\right)+\left(a^{2} S E_{b}^{2}\right)}}
$$

Where:

$\mathrm{a}=$ independent variable regression coefficient against mediation variables.

$\mathrm{b}=$ coefficient of regression of mediation variable to dependent variable.

$\mathrm{SE}=$ standart error of estimation from the influence of independent variables on mediation variables.

$\mathrm{SE}=$ standart error of estimation from the influence of mediation variables on dependent variables.

\section{RESULT AND DISCUSSION}

Researchers to obtain the results of this study used several data analysis including: correlation coefficient test, simple linear regression test, determination coefficient, multiple linear regression test and significance test. Based on the results of tests that have been done in MSMEs in Babakan Madang and Cisarua Kabupatean Bogor subdistricts, the following results are obtained:

Table. 1 . Research Results

\begin{tabular}{|l|l|l|l|c|l|}
\hline \multirow{4}{*}{ No. } & \multirow{4}{*}{ Hypothesis Test } & \multirow{4}{*}{$\begin{array}{l}\text { Correlatio } \\
\text { n Test }\end{array}$} & \multicolumn{2}{|l|}{ Test Results } & $\begin{array}{l}\text { Descriptio } \\
\mathbf{n} \\
\text { Hypothesis }\end{array}$ \\
\cline { 4 - 5 } & & $\begin{array}{l}\text { Detreminatio } \\
\text { n }\end{array}$ & $\begin{array}{c}\text { t/f } \\
\text { Coun }\end{array}$ & \\
\hline
\end{tabular}

http://ijstm.inarah.co.id 


\begin{tabular}{|c|l|c|c|c|c|}
\hline 1 & \multicolumn{1}{|c|}{$\begin{array}{l}\text { t } \\
\text { 2apital to employee } \\
\text { performance }\end{array}$} & 0,408 & $16,66 \%$ & 4,282 & Ha received \\
\hline 2. & $\begin{array}{l}\text { Capital towards } \\
\text { marketing }\end{array}$ & 0,752 & $56,74 \%$ & 3,573 & Ha received \\
\hline 3. & $\begin{array}{l}\text { Work environment to } \\
\text { employee performance }\end{array}$ & 0,686 & $46,6 \%$ & 8,985 & Ha received \\
\hline 5. & $\begin{array}{l}\text { Work environment } \\
\text { towards marketing }\end{array}$ & 0,630 & $39,20 \%$ & 7,684 & Ha received \\
\hline Marketing as a & $\begin{array}{l}\text { Variable to employee } \\
\text { performance }\end{array}$ & 0,629 & $39,23 \%$ & 3,608 & Ha received \\
\hline 6. & $\begin{array}{l}\text { Capital to employee } \\
\text { performance through } \\
\text { marketing }\end{array}$ & 0,517 & $27,43 \%$ & 5,834 & Ha received \\
\hline & $\begin{array}{l}\text { Work environment to } \\
\text { employee performance } \\
\text { through marketing }\end{array}$ & 0,294 & $8,74 \%$ & 2,943 & Ha received \\
\hline
\end{tabular}

Based on Table 1, it can be known that the results of t (partial significance test) and sobel test (simultaneous or joint significance test) show that:

1. Capital has an influence on employee performance where the value of $t$ calculate $(4,282)>t$ table $(1,986)$ so that the hypothesis is accepted.

2. Capital has an influence on marketing, where the value $t$ calculate $(3,573)>t$ table $(1,986)$ so the hypothesis is accepted.

3. The work environment has an influence on employee performance where the value of $t$ calculates $(8,985)>t$ table $(1,986)$ so that the hypothesis is accepted.

4. Performance environment has an influence on marketing where the value $t$ calculates $(7,684)>t$ table $(1,986)$ so the hypothesis is accepted.

5. Marketing has an influence on employee performance where the value $t$ calculates $(3,608)>t$ table $(1,986)$ so that the hypothesis is accepted

6. Capital has an influence on employee performance through marketing where the value of $t$ calculate $(5,834)>t$ table $(1,986)$ so that the hypothesis is accepted.

7. The work environment has an influence on employee performance through marketing where the value of $t$ calculates $(2,943)>t$ table $(1,986)$ so that the hypothesis is accepted.

Table 2. Results of Capital Regression Test on Employee Performance Coefficients $^{\mathrm{a}}$

\begin{tabular}{|l|l|l|l|l|}
\hline & & $\begin{array}{l}\text { Standardi } \\
\text { zed }\end{array}$ & & \\
\hline
\end{tabular}




\begin{tabular}{|c|c|c|c|c|c|}
\hline \multirow[b]{2}{*}{ Model } & \multicolumn{2}{|c|}{$\begin{array}{l}\text { Unstandardized } \\
\text { Coefficients }\end{array}$} & \multirow{2}{*}{$\begin{array}{l}\begin{array}{l}\text { Coefficie } \\
\text { nts }\end{array} \\
\begin{array}{c}\mathrm{Be} \\
\mathrm{ta}\end{array}\end{array}$} & \multirow[b]{2}{*}{$\mathrm{T}$} & \multirow[b]{2}{*}{$\begin{array}{c}\text { Sig } \\
.\end{array}$} \\
\hline & $\mathrm{B}$ & Std. Error & & & \\
\hline $\begin{array}{ll}1 & \\
(\text { Constan } \\
\text { t) } & \\
& \text { total }\end{array}$ & $.379^{8.936}$ & $\begin{array}{l}1.352 \\
.086\end{array}$ & .407. & \begin{tabular}{r|}
6.595 \\
4.2 \\
83
\end{tabular} & $\begin{array}{l}.000 \\
.000\end{array}$ \\
\hline
\end{tabular}

a. $\quad$ Dependent Variable: totall

Based on Table 2, it can be determined that the regression coefficient value for the business capital variable is positive value of 0.379 . This indicates that the Capital variable has a positive relationship with employee performance, where it can be said that the more capital given, the better the level of Employee Performance.

Table 3. Capital Regression Test Results Against Marketing

\section{Coefficients $^{\mathrm{a}}$}

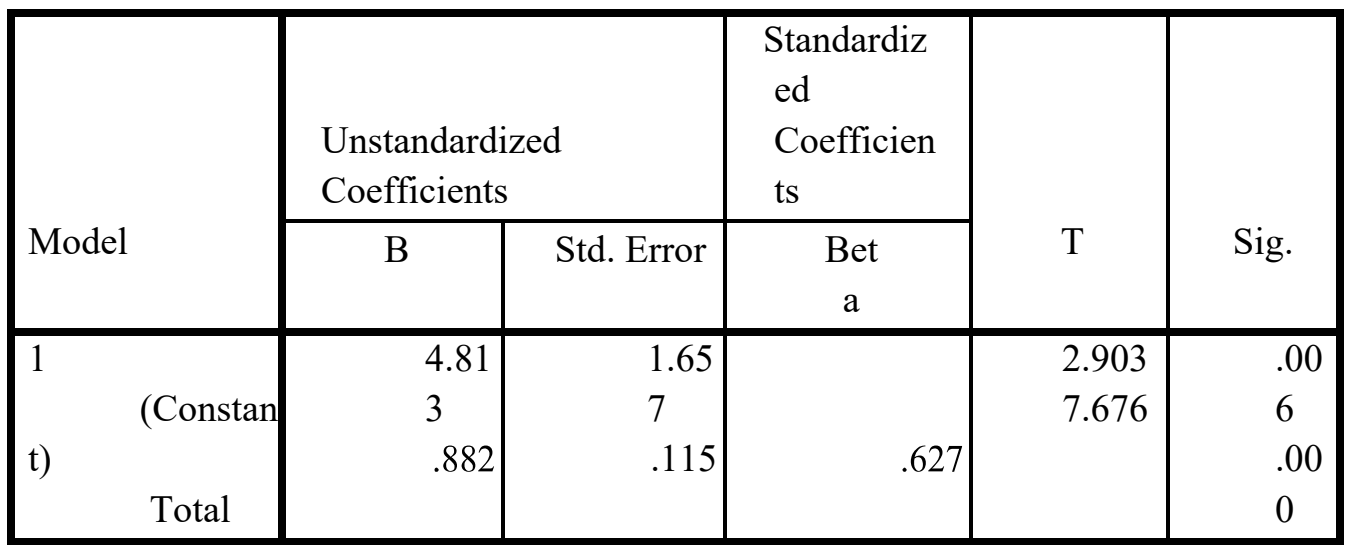

a. Dependent Variable: total

Based on Table 3 it can be found that the value of the $\mathrm{v}$ regression coefficient for the capital variable is positive value of 0.882 . This indicates that capital variables have a positive relationship with Marketing, where it can be said that the more capital given, the higher the level of marketing.

Table 4. Results of Work Environment Regression Test on Employee Performance Coefficients $^{\mathrm{a}}$

\begin{tabular}{|c|c|c|c|c|c|}
\hline \multirow[b]{2}{*}{ Model } & \multicolumn{2}{|c|}{$\begin{array}{l}\text { Unstandardized } \\
\text { Coefficients }\end{array}$} & $\begin{array}{r}\text { Standardized } \\
\text { Coefficients }\end{array}$ & & \\
\hline & B & Std. Error & Beta & $\mathrm{T}$ & Sig. \\
\hline
\end{tabular}




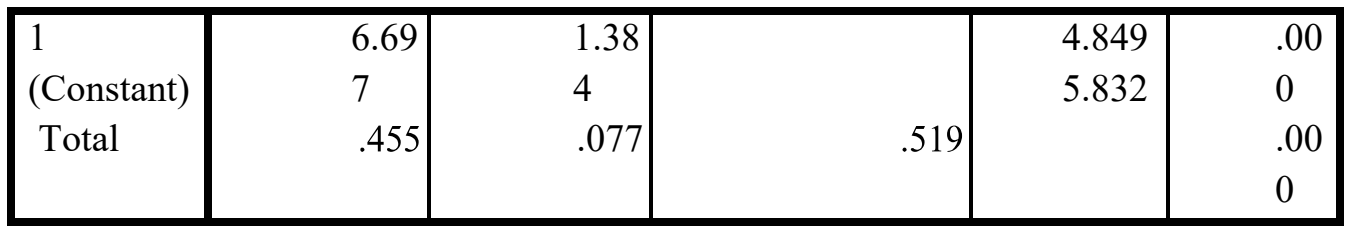

a. Dependent Variable: totall

Based on Table 4 it can be found that the regression coefficient value for the work environment variable is positive value of 0.455 . This indicates that the variables of the work environment have a positive relationship with employee performance, where it can be said that the better the work environment, the better the level of employee performance.

Table 5. Results of Work Environment Regression Test Against Marketing

\section{Coefficients $^{\mathrm{a}}$}

\begin{tabular}{|c|c|c|c|c|c|}
\hline \multirow[b]{2}{*}{ Model } & \multicolumn{2}{|c|}{ Unstandardized Coefficients } & $\begin{array}{r}\text { Standardized } \\
\text { Coefficients }\end{array}$ & \multirow[b]{2}{*}{$\mathrm{T}$} & \multirow[b]{2}{*}{ Sig. } \\
\hline & B & $\begin{array}{l}\text { Std. } \\
\text { Error }\end{array}$ & Beta & & \\
\hline $\begin{array}{cc}1 & \text { (Constant) } \\
\text { Total }\end{array}$ & $.815^{3.045}$ & & 683 & $\begin{array}{l}1.887 \\
8.990\end{array}$ & $\begin{array}{l}.063 \\
.000\end{array}$ \\
\hline & & . 091 & & & \\
\hline
\end{tabular}

a. Dependent Variable: total

Based on Table 5, it is known that the regression coefficient value for the work environment variable is positive at 0.815 . This indicates that the variables of the work environment have a positive relationship with marketing, where it can be said that the better the work environment, the higher the level of marketing.

Table 6. Results of Marketing Regression Test on Employee Performance

\section{Coefficients $^{\mathrm{a}}$}

\begin{tabular}{|c|c|c|c|c|c|}
\hline \multirow[b]{2}{*}{ Model } & \multicolumn{2}{|c|}{ Unstandardized Coefficients } & $\begin{array}{l}\text { Standardize } \\
\mathrm{d} \\
\text { Coefficient } \\
\mathrm{s}\end{array}$ & \multirow[b]{2}{*}{$\mathrm{T}$} & \multirow[b]{2}{*}{$\begin{array}{l}\mathrm{S} \\
\mathrm{i} \\
\mathrm{g}\end{array}$} \\
\hline & B & Std. Error & $\begin{array}{c}\text { Bet } \\
\mathrm{a}\end{array}$ & & \\
\hline $\begin{array}{ll}1 & \text { (Constant } \\
& \\
& \text { Total }\end{array}$ & $\begin{array}{l}11.72 \\
7 \\
.374\end{array}$ & $\begin{array}{l}1.94 \\
2 \\
.127\end{array}$ & .294 & $\begin{array}{l}6.042 \\
2.938\end{array}$ & $\begin{array}{l}.000 \\
.004\end{array}$ \\
\hline
\end{tabular}


a. Dependent Variable: totall

Based on Table 6, it is known that the regression coefficient value for marketing variables is positive value of 0.374 . This indicates that marketing variables have a positive relationship with employee performance, where it can be said that the higher the marketing, the better the level of employee performance .

\section{CONCLUSION}

1. The effect of capital variables on employee performance variables, based on data analysis and hypothesis testing that I conducted in this research, it is known that:

a. Capital has an influence on employee performance where the value of $t$ calculates $(4,282)>t$ table $(1,986)$ so that the hypothesis is accepted.

b. It is known that the regression coefficient value for the Capital variable is positive value of 0.379 . This indicates that the Capital variable has a positive relationship with employee performance, where it can be said that the greater the capital given, the better the level of Employee Performance.

2. The effect of capital variables on marketing variables, based on data analysis and hypothesis testing conducted in this research, it is known that:

a. Capital has an influence on marketing, where the value of $t$ calculates $(3,573) \mathrm{t}$ table $(1,986)$ so that the hypothesis is accepted.

b. It is known that the regression coefficient value for capital variables is positive value of 0.882 . This indicates that capital variables have a positive relationship with marketing, where it can be said that the better the capital, the higher the level of investment.

3.The effect of work environment variables on employee performance variables, based on data analysis and hypothesis testing conducted in this research, it is known that:

a. The work environment has an influence on employee performance where the value of $t$ calculates $(8,985)>t$ table $(1,986)$ so that the hypothesis is accepted.

b. It is known that the regression coefficient value for the pemasran variable is positive at 0.455 . This indicates that the variables of the work environment have a positive relationship with employee performance, where it can be said that the better the work environment, the better the employee performance.

4. The effect of work environment variables on marketing variables, based on data analysis and hypothesis testing conducted in this research, it is known that: 
a. The work environment has an influence on marketing where the value $t$ calculates $(7,684)>t$ table $(1,986)$

b. It is known that the regression coefficient value for marketing variables is positive value of 0.815 . This indicates that the variables of the work environment have a positive relationship with marketing, where it can be said that the better the work environment, the higher the motivation level.

5. The effect of marketing variables on Employee Performance Variables, based on data analysis and hypothesis testing conducted in this research, it is known that:

a. Marketing ability has an influence on employee kineja where the value of $t$ calculate $(3,608)>t$ table $(1,986)$ so that the hypothesis is accepted.

b. It is known that the regression coefficient value for the motivation variable is positive value of 0.374 . This indicates that marketing variables have a positive relationship with employee performance, where it can be said that the higher the marketing, the better the level of employee performance.

6. The influence of capital variables on employee performance variables, based on data analysis and hypothesis testing conducted in this study, it is known that: Capital has an influence on employee performance through marketing where the value of $t$ calculate $(5,834)>t$ table $(1,986)$ so that the hypothesis is accepted.

7. The effect of work environment variables on employee performance variables, based on data analysis and hypothesis testing conducted in this study, it is known that: the work environment has an influence on Employee Performance through marketing where the value of $t$ calculate $(2,943)>t$ table $(1,986)$ so that the hypothesis is accepted.

\section{ACKNOWLEDGMENTS}

We would like to thank all the good parties in this activity, especially from:

1. Dr. Dede Kardaya, Ir.,M.Si. As Rector of Djuanda University

2. Dr. Lucky Hikmat Maulana, SE. M.Si. As Dean of Faculty of Economics

3. Endang Silaningsih, SE.,MM. As a Place of Work Management Study Program

4. Head of Cibeureum Village, Cisarua SubDistrict and staff

5. Head of Karang Tengah Village, Babakan Madang SubDistrict and staff

6. Julaekha, A.Md. As Head of MSME Cibeureum Village and owner of MSME Wingko products in Cibeureum Village Cisarua District 
7. Mamat, As the owner of GEMBLONG PRODUCT MSME in Cibeureum Village Cisarua District

8. MSMEs in Karang Tengah sub-district of Babakan Madang

9. People from Cibeureum and Karang Tenga villages

10. Students of KKN Universitas Djuanda Bogor

\section{REFERENCES}

[1] Kotler dan Kevin Lane Keller. 2009. Manajemen Pemasaran. Edisi ke 13. Jakarta: Erlangga.h.12

[2] Ali, A. dan Agustin, S. (2015), "Pengaruh Struktur Modal Terhadap Profitabilitas Pada Perusahaan Telekomunikasi," Jurnal Ilmu dan Riset Manajemen Vol. 4, No. 9, Agustus 2015.

[3] Syafri . 2005. Analisis Kritis Laporan Keuangan. Jakarta: Raja Grafindo Persada, h. 211

[5] Isyandi, B. 2014. Manajemen Sumber Daya Manusia dalam Persepektif Global. Penerbit : UNRI Press, Pekanbaru, h.134

[6] Stanton, William J. 2013. Prinsip Pemasaran. Alih Bahasa oleh Buchari Alma. Jilid Satu. Edisi Kesepuluh. Jakarta : Erlangga.h.1293

[7] Kotler, Philip dan Amstrong, Gary, (2014), Principles of Marketin, 12th Edition, Jilid 1 Terjemahan Bob Sabran Jakarta : Erlangga. H.29

[8] Sudaryono. 2016. Manajemen Pemasaran Teori Dan Implementasi. Yogyakarta: ANDI, h. 41

[9] A.A. Anwar Prabu Mangkunegara, 2013, Manajemen Sumber Daya Manusia Perusahaan. Bandung: PT. Remaja Rosda Karya.h.67

[10] Amirullah, 2015. Pengantar Manajemen. Jakarta: Mitra Wacana Media.h.231

[11] Simanjuntak, P. J. (2011). Manajemen dan Evaluasi Kinerja Lembaga Penerbit FEUI. h.1

[12] Moeheriono. 2012. "Pengukuran Kinerja Berbasis Kompetensi". Jakarta: Raja Grafindo Persada. H.69

[13] Moeheriono. 2010. Pengukuran Kinerja Berbasis Kompetensi. Bandung : Ghalia Indonesia. H.11

[14] Nicole A. Healy, Tammy H. Scheidegger, Amy L. Ridley Meyers, and Karen Friedlen. 2009. The Relationship Between Psychological Birth Order and Romantic Relationships. American Counseling association Annual Corference and Exposition March 19-23, Charlotte, North Carolina. (online). Tersedia : http://sagepub.com/cgi/relationship/2009/3/19-23J.

[15] Ahmed, S \& Rahman, H. (2015). The Effects Of Marketing Mix On Consumer Satisfaction: A Literature Review From Islamic Perspectives . Turkish Journal of Islamic Economics, Vol. 2, No. 1, February 2015, pp. 17-30, pp 17-30 Vol.2, No. 1. 